\title{
The Effect of Pressure or Flow Stress on Right Ventricular Protein Synthesis in the Face of Constant and Restricted Coronary Perfusion
}

\author{
Smney S. Schretber, Marcus A. Rothschimd, Carole Evans, \\ Franctne RefF, and Murray Oratz \\ From the Radioisotope Service, New York Veterans Administration Hospital; \\ the Department of Medicine, New York University School of Medicine; and \\ the Department of Biochemistry, New York University College of Dentistry, \\ New York 10010
}

\begin{abstract}
A B S T R A C T Cardiac stress produced by hypertension or excess volume loading results in different types of hypertrophy. Elevated left ventricular pressure rapidly results in increased myocardial protein synthesis in vivo and in vitro, but such rapid alterations are not consistently seen in volume loading. The difference in response is difficult to clarify since it is not possible to effect alterations in left ventricular pressure or perfusion without profoundly affecting coronary perfusion. The present study describes cardiac protein synthesis in the right ventricle of the young guinea pig heart in vitro by utilizing a perfusion model in which the right ventricle could be stressed by elevations of pressure or volume loading in the presence of constant and restricted coronary perfusion. With coronary flow maintained at $4 \mathrm{ml} / \mathrm{min}$ per heart equivalent to $25 \mathrm{ml} / \mathrm{min} / \mathrm{g}$ dry wt, an increase in right ventricular pressure from normal levels of $3 \mathrm{~mm} \mathrm{Hg}$ to $11 \mathrm{~mm} \mathrm{Hg}$ resulted in a $60 \%$ increase of myocardial incorporation of $\left[{ }^{\mathrm{x}} \mathrm{C}\right]$ lysine into protein. However, with further increases of right ventricular pressure to $22 \mathrm{~mm} \mathrm{Hg}$, protein synthesis dropped back to normal levels. The falloff in protein synthesis was not due to decreased contractility, alterations in intracellular lysine pool specific activity, or alterations in distribution of coronary flow. A $60 \%$ increase in coronary perfusion was again associated with a similar response of protein synthesis to progressive elevations of pressure despite a rise in the ATP levels and a fall in lactate production. Thus, a deficiency of $\mathrm{O}_{2}$ did not entirely explain the decline of protein synthesis with maximal pressures. At all levels of coronary perfusion, volume loading for $3 \mathrm{~h}$ did not result in increased protein incorporation of $\left[{ }^{14} \mathrm{C}\right]$ lysine. The studies support a rela-
\end{abstract}

Received for publication 8 October 1973 and in revised form 16 September 1974. tionship between ventricular pressure and protein synthesis unrelated to coronary flow per se. A pressure receptor triggering protein synthesis within the ventricular wall is postulated. Such a relationship is not apparent in short-term volume loading in vitro.

\section{INTRODUCTION}

Cardiac stress produced by experimental hypertension or excess volume loading eventually results in hypertrophy (1-3) though the mechanisms and types of hypertrophy may be different in each stress, e.g., concentric hypertrophy with little increase in ventricular volume is described in hypertension or valvular stenosis while hypertrophy with dilatation is most often seen in valvular insufficiency or volume stress $(4,5)$. Acute aortic hypertension or volume loading is also accompanied by increased coronary flow which has been shown to enhance protein synthesis (6-8), and few data are available on the effects of such loading in the face of controlled or restricted coronary perfusion.

The present report presents data obtained with an in vitro perfusion modal which was designed to separate pressure and volume stresses in the right ventricle from alterations in coronary perfusion and which permits study of protein synthesis in this ventricle in the presence of controlled as well as restricted coronary flow. Two patterns are indicated with this model of the young guinea pig heart. First, protein synthesis is stimulated by acute pressure stress but not by acute volume loading. Second, with maximum stresses right ventricular protein synthesis returns to control levels. A preliminary description of this model was previously reported (9).

\section{METHODS}

Young male guinea pigs, 260-320 g, approximately 4-6 wk after weaning, were used in all the studies. The diet before

The Journal of Clinical Investigation Volume 55 January 1975.1-11 
the operation and anesthesia were as described previously $(6,7)$. After anesthesia, the chest cage was opened and the proximal aorta cannulated and perfused with oxygenated Krebs-Henseleit solution containing amino acids in concentrations previously described $(6,10)$. The pulmonary artery was then cannulated with a no. 240 nondistensible polyethylene catheter which was gently passed through the pulmonic valve into the right ventricular cavity and secured. The pulmonary arteries and veins were then ligated at the hilar regions and the lungs removed.

The inferior vena cava was then cannulated with the cannula entering the inferior portion of the right atrium and secured in that position. The right atrium was converted into a closed chamber by ligating the superior vena cava. Similarly by ligation of the pulmonary veins, the left atrium was also a closed chamber. Any significant aortic regurgitation during the retrograde aortic perfusion could be immediately seen by dilatation of the left ventricle and atrium.

The heart and cannulae were transferred to a temperature-controlled perfusion chamber containing oxygenated Krebs-Henseleit solution which bathed the preparation (Fig. 1). The heart was perfused by two separate circulations (Fig. 2). The first system perfused the coronary circulation via the aorta with a roller pump, and the flow was carefully regulated and continuously measured by a flow meter. With the pump used, (rotary type, model 375, Sage Instruments Div., Orion Research, Inc., Cambridge, Mass.) it was possible to maintain the total coronary flow at exactly the rate desired despite alterations in pressure or possible coronary vasodilation or vasoconstriction. The aortic and hence coronary pressures were continuously monitored by a pressure transducer ( $\mathrm{P} 23 \mathrm{DB}$, Statham Instruments, Inc., Oxnard, Calif.) connected by a $\mathrm{T}$ tube to the aorta above the coronary ostia. The coronary perfusion fluid containing Krebs-Henseleit solution with amino acids (6) continuously oxygenated with $95 \% \quad \mathrm{O}_{2}-5 \% \quad \mathrm{CO}_{2}$, at a

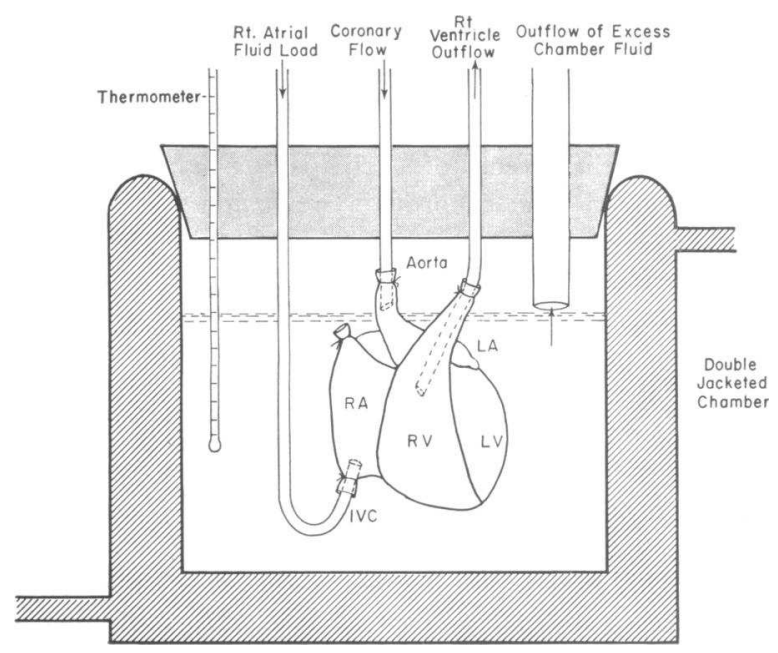

FIGURE 1 Perfusion chamber for right ventricular stress with controlled coronary artery perfusion. See Methods. IVC, inferior vena cava; LA, left atrium; LV, left ventricle; RA, right atrium; $\mathrm{RV}$, right ventricle.
$\mathrm{pH}$ of $7.4(6,7,10)$ emptied into the right atrium, right ventricle and was ejected by the ventricle through the right ventricular cannula. The perfusate was not reutilized.

The second perfusion system, using identical perfusion fluid as the coronary circulation, presented a known fluid load to the right atrium through the inferior vena cava cannula. This flow was also regulated and could be varied as desired by a micrometer-controlled Sage roller pump and continuously measured with a flow meter. Thus, the right atrium was a closed system which received the coronary flow plus the flow from the inferior vena cava. The combined right atrial fluid volume passed into the right ventricle and was thence ejected by ventricular systole. Right ventricular outflow was carried by the rigid ventricular no. 240 catheter through a microstopcock regulator and a flow meter. The right ventricular outflow was also connected to a separate pressure transducer by a $\mathrm{T}$ tube so that right ventricular cavity systolic and diastolic pressures were continuously measured throughout the perfusion period. Right ventricular pressure was elevated by narrowing the bore of the right ventricular-pulmonary artery catheter with the microstopcock. Since this catheter was secured with a ligature about the artery there was no leak from the ventricle. With the stopcock wide open, right ventricular cavity systolic pressures were $3-5 \mathrm{~mm} \mathrm{Hg}$ with the flows used in this study.

The hearts were perfused for $3 \mathrm{~h}$ under conditions of pressure or flow required by the study. The parameters measured included total coronary perfusion $(\mathrm{ml} / \mathrm{min})$, coronary artery pressure $(\mathrm{mm} \mathrm{Hg})$, right atrial fluid load (ml/ min), right ventricular systolic and diastolic pressures (mm $\mathrm{Hg})$, cardiac rate, right ventricular ejection volume ( $\mathrm{ml} /$ min), amplitude of contraction $(\mathrm{mm} \mathrm{Hg}$ ) (defined as $\Delta \mathrm{P}$ or the difference between right ventricular systolic and diastolic pressures), and $\mathrm{dP} / \mathrm{dT} \max$ obtained from the 50 $\mathrm{mm} / \mathrm{s}$ tracings of right ventricular cavity pressures or directly from a Hewlitt-Packard derivative computer (model 8814 A, Hewlitt-Packard Co., Palo Alto, Calif.) connected to the pressure recorder.

At the end of the perfusion period, the parameters measured were averaged and recorded (Tables $\mathrm{I}$ and $\mathrm{V}$ ). Ventricular contraction was also evaluated by comparing the "amplitude" of contraction during the last $10 \mathrm{~min}$ of perfusion with that at the first $10 \mathrm{~min}$, and the ratio of amplitudes (end/onset) recorded as an index of competence.

In the guinea pig, the average heart weight is $1.0 \mathrm{~g}$. In the first grcup of studies, the coronary flow was maintained at exactly $4.0 \mathrm{ml} / \mathrm{min}$ per heart equivalent to $25-26 \mathrm{ml} /$ $\mathrm{min} / \mathrm{g}$ dry ventricular wt. The variation in the actual flow/ dry wt was due to the slight variation in heart weights. In the second group of studies, the coronary flow was $6.0 \mathrm{ml} / \mathrm{min}$ for all the hearts in the group (approximately $39-42 \mathrm{ml} / \mathrm{min} / \mathrm{g}$ dry $\mathrm{wt}$ ).

Measurements of protein synthesis prcceeding during the $3 \mathrm{~h}$ of perfusion were made by using $\left[{ }^{14} \mathrm{C}\right]$ lysine in the perfusate (sp act $25 \mu \mathrm{Ci} / \mu \mathrm{mol}$, uniformly labeled, $98 \%$ purity by column as L-lysine, New England Nuclear, Boston, Mass.). The purity was verified by analysis for lysine on an amino acid analyzer before and after treatment with lysine decarboxylase to assure all material used was Llysine. Protein synthesis was defined as incorporation of the labeled lysine into isolated and purified mixed cardiac protein and was calculated from the measurements of the radioactive lysine in the protein and the specific activity of t'ie intracellular free $\left[{ }^{14} \mathrm{C}\right]$ lysine pool. Thus, synthesis was defined and expressed as micromoles lysine incorporated into 


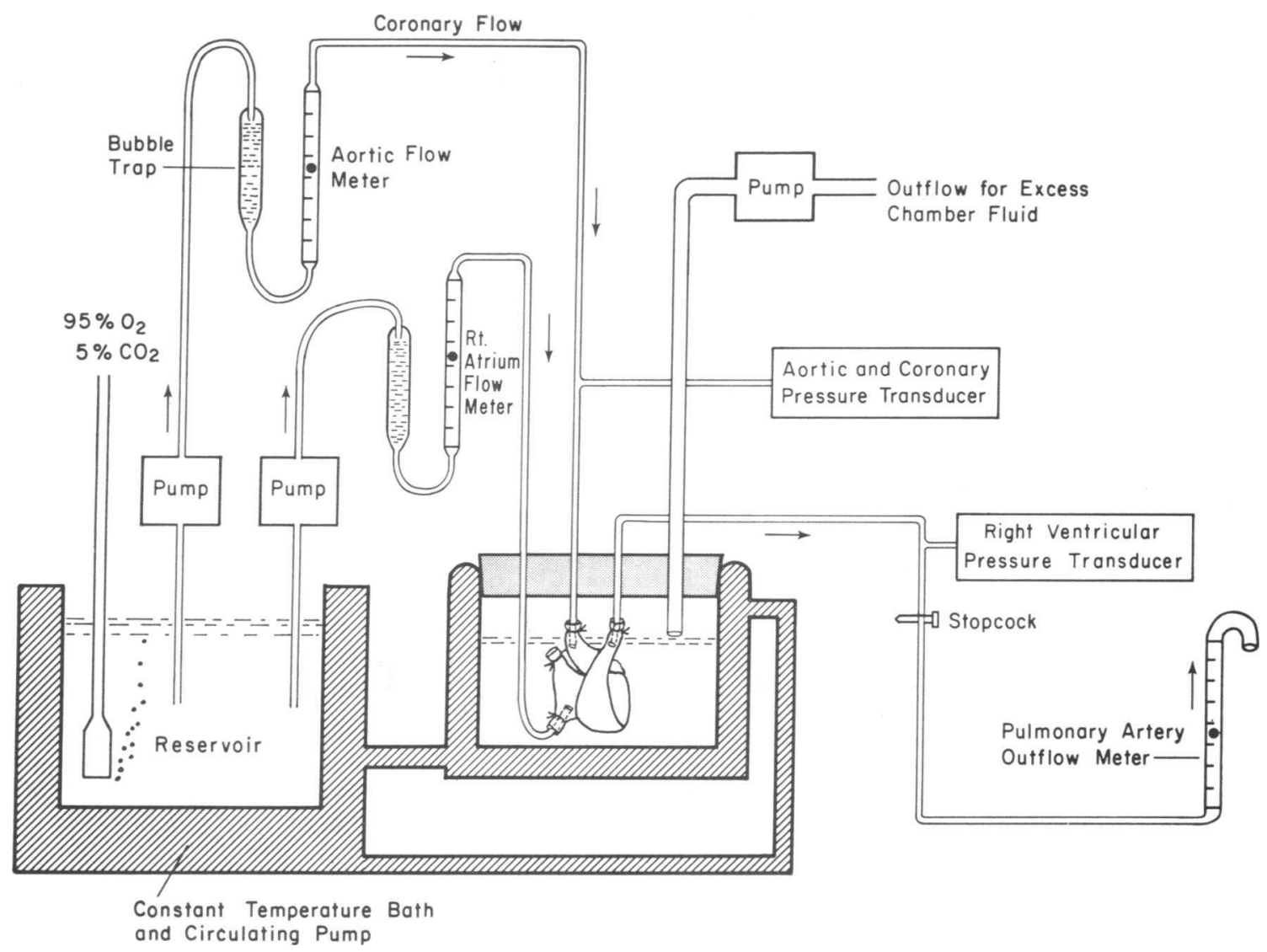

FIgURE 2 Perfusion apparatus for inducing either right ventricular pressure or volume load stress in the face of constant coronary artery perfusion. As indicated in Fig. 1, the pulmonary artery catheter entered the right ventricular cavity and the pressures recorded were right ventricular cavity pressures. Although it appears to be placed higher in the diagram, the transducer was at the same level as the heart.

protein per gram protein $\mathrm{N}$ calculated from the fraction: $\mu \mathrm{mol}$ lysine $/ \mathrm{g}$ protein $\mathrm{N}=$

$$
\begin{gathered}
\text { cpm }\left[{ }^{14} \mathrm{C}\right] \text { lysine per } \mathrm{g} \text { protein } \mathrm{N} \\
\text { intracellular free }\left[{ }^{14} \mathrm{C}\right] \text { lysine sp act } \\
\left(\mathrm{cpm}\left[{ }^{14} \mathrm{C}\right] \text { lysine per } \mu \text { mol lysine }\right)
\end{gathered}
$$

The measurement of the intracellular free lysine pool specific activity was carried out as has been described previously (10).

Isolation of mixed cardiac protein. At the end of perfusion, the right ventricular wall was separated from the heart and taken as the source of right ventricular protein. Isolation and purification of protein including homogenization in ice-cold 5\% trichloracetic acid (TCA), washing repeatedly in TCA containing nonradioactive lysine and then in lysine-free TCA, extraction with hot $\left(95^{\circ} \mathrm{C}\right) \mathrm{TCA}$ to hydrolyze and remove tRNA, fat extraction with ethanolchloroform-ether, drying in ether, and solution of the dried protein in concentrated formic acid were as described previorsly $(6,7,10)$. Similarly, assay of the $\left[{ }^{14} \mathrm{C}\right]$ lysine activity in the dissolved protein was as described with the use of internal standards to correct for quenching in an ambient temperature liquid scintillation counter with an efficiency for ${ }^{14} \mathrm{C}$ of $50 \%,(6,7,10)$.

Coronary circulation. To ascertain whether there was a shunting of coronary flow away from the right ventricle as the ventricular pressure was increased, 31 hearts were perfused at high and low pressures with [ $\left.{ }^{181} \mathrm{I}\right]$ albumin or macroaggregated $\left[{ }^{131} \mathrm{I}\right]$ albumin. A separate perfusion pump, flow meter, and reservoir containing the identical perfusate used in the study with added Cardio-Green $(4 \mathrm{mg} / 100 \mathrm{ml})$ (Hynson, Westcott \& Dunning Inc., Baltimore) and [ $\left.{ }^{131} \mathrm{I}\right]$ albumin $\left(20 \mu \mathrm{Ci}\left[{ }^{131} \mathrm{I}\right]\right.$ albumin mixed with $500 \mathrm{mg}$ albumin/ $100 \mathrm{ml}$ perfusate) was switched to the coronary artery circulation and maintained at the same conditions as the prior perfusion period. The Cardio-Green was used as a visible label to determine the "zero time" when the dye first entered the aortic cannula. At the appearance of the dye in the right atrium, the right and left ventricular walls were immediately removed from the rest of the heart and gently blotted dry. The [ $\left.{ }^{181} \mathrm{I}\right]$ albumin activity was then determined in a weighed portion of each ventricle, and activity was expressed as counts per minute per gram of right or left ventricle.

Normal guinea pig cardiac pressure. To approximate the right ventricular pressures in the intact baby guinea pig, 


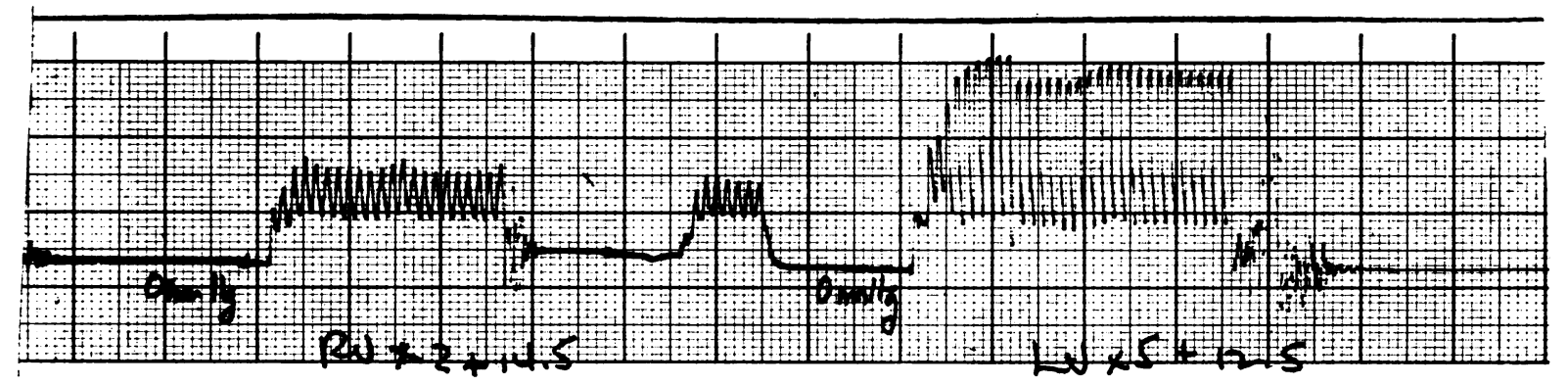

FIGURE 3 Measurement of intracavitary pressures in right and left ventricle of a lightly anesthetized oxygen-breathing baby guinea pig (weight $290 \mathrm{~g}$, age $3 \mathrm{wk}$ post weaning). For description see Methods. The left tracing is the recording of the pressure in the right ventricle. Each box on the vertical scale $=0.4 \mathrm{~mm} \mathrm{Hg}$. The zero line was positioned at 14.5 vertical boxes or $10 \mathrm{~mm} \mathrm{Hg}$. Subtracting the peak right ventricular systolic reading from the zero point gave a ventricular reading of $4.0 \mathrm{~mm} \mathrm{Hg}$. Similarly, the recording on the right is that within the left ventricle of the same animal with each vertical box $=1.0 \mathrm{~mm} \mathrm{Hg}$. Subtracting the peak systolic reading from the zero point gives a ventricular pressure in this animal of $29 \mathrm{~mm} \mathrm{Hg}$.

measurements of the right ventricular cavity pressures were carried out in the lightly anesthetized and oxygenbreathing animal. Ether anesthesia was regularly found to produce breath holding and was discarded in favor of light Nembutal anesthesia.

With continuous oxygen breathing, the sternum was split, and a no. 23 needle inserted into the pulmonary artery without compromising the pleural cavities. Respiration was continued and oxygenation of the blood was unaffected. In two separate studies, the peak systolic right ventricular pressures were 4-5 $\mathrm{mm} \mathrm{Hg}$. In six additional studies, after anesthesia and with continuous oxygen breathing, the right ventricle was approached transthoracically and a no. 18 needle inserted into the right ventricular cavity and tracings were recorded. In the six studies, the peak systolic pressure in the right ventricle was $4 \pm 1 \mathrm{~mm} \mathrm{Hg}$ (Fig. 3). In the same animals, the left ventricular cavity pressure was also recorded transthoracically by piercing the interventricular septum. The mean left ventricular pressure was $36 \pm 4 \mathrm{~mm}$ Hg. The latter is similar to readings obtained with the abdominal aorta cannulation in the anesthetized animal of this age reported earlier (10).

Right ventricular $A T P$ content, expressed as micromoles ATP per gram ventricular nitrogen, was determined in hearts perfused for $3 \mathrm{~h}$ with right ventricular pressures from 4 to $22 \mathrm{~mm} \mathrm{Hg}$. At the end of perfusion, while the coronary perfusion was continued at the experimental level, a section of right ventricular wall was cut with one motion from the heart and instantly frozen by clamping with a Wollenberger type clamp at the temperature of liquid nitrogen. ATP was assayed by a luciferin-luciferase method previously described (11). In addition, ATP was assayed in hearts perfused for only $30 \mathrm{~min}$ to $1 \mathrm{~h}$, as well as in hearts obtained from lightly anesthetized and oxygen-breathing $300-\mathrm{g}$ guinea pigs. Assay of the latter in 16 separate studies gave a mean value of $193 \pm 8$ (SE) $\mu \mathrm{mol} / \mathrm{g}$ ventricular nitrogen equivalent to $4.8-5.0 \mu \mathrm{mol} / \mathrm{g}$ wet $\mathrm{wt}$. These values are similar to those reported elsewhere for the guinea pig (11). Chemical methods of determinations of protein $\mathrm{N}$, isolation of $\left[{ }^{14} \mathrm{C}\right]$ lysine and determination of the $\left[{ }^{14} \mathrm{C}\right]$ lysine specific activity with an amino acid analyzer were carried out as reported previously $(6,7,10)$.
Lactate production by hearts subjected to right ventricular afterload stresses was determined by collecting all of the effluent from the heart for $30-40 \mathrm{~min}$ as well as from the bath surrounding the heart. Lactate was determined with the aid of Lactic Acid Kit no. 826B of Sigma Chemical Co., St. Louis, Mo., and the results expressed as micromoles lactate per minute per gram wet wt. Lactate content of the right ventricles was also determined at the end of the perfusion period in 14 studies.

\section{RESULTS}

Increasing right ventricular pressure (afterload) in the face of restricted and constant total coronary perfusion $(4.0 \mathrm{ml} / \mathrm{min}$ per heart) and constant atrial fluid load

Measurement of the right ventricular cavity pressure in situ revealed a mean peak systolic pressure of 3-5 $\mathrm{mm} \mathrm{Hg}$ (see Methods) (Fig. 3). Three levels of right ventricular pressure were studied in the perfusion model in vitro (Table I, groups I, II, and III). First, with the mean systolic pressure close to that seen in situ, $3 \mathrm{~mm}$ $\mathrm{Hg}$; second, with narrowing of the pulmonary cannula and increased pulmonary resistance so that the right ventricular systolic pressure increased 3-4-fold (11 mm $\mathrm{Hg}$ ) ; and third, with further restriction to outflow so that right ventricular systolic pressure increased to 22 $\mathrm{mm} \mathrm{Hg}$. The last level was selected since levels higher than $30 \mathrm{~mm} \mathrm{Hg}$ frequently resulted in rupture or leaking of the preparation. In all three groups, the coronary flow was restricted to $4.0 \mathrm{ml} / \mathrm{min}$ per heart averaging $1.0 \mathrm{~g}$ in wet wt equivalent to $25-26 \mathrm{ml} / \mathrm{min} / \mathrm{g}$ dry wt. Similarly, in all three groups, the right atrial perfusion load was constant at $2.0 \mathrm{ml} / \mathrm{min}(14 \mathrm{ml} / \mathrm{min} / \mathrm{g}$ dry wt) or a total of $6 \mathrm{ml} / \mathrm{min}(4.0 \mathrm{ml}$ from coronary perfusion $+2.0 \mathrm{ml}$ directly to the right atrium). With a rise in pulmonary outflow resistance and a significant eleva- 
TABLE I

Protein Synthesis in Right Ventricles with Restricted and Constant Coronary Flow $(4 \mathrm{ml} / \mathrm{min} / \mathrm{heart}$ or $25 \mathrm{ml} / \mathrm{min} / \mathrm{g} d r y$ wt) with Changes in Right Ventricular Pressure or Right Atrial Fluid Load

\begin{tabular}{|c|c|c|c|c|c|c|c|c|}
\hline \multirow[b]{2}{*}{ Group } & \multicolumn{2}{|c|}{ Right ventricular pressure } & \multirow{2}{*}{$\begin{array}{c}\text { Amplitude } \\
\text { (mean) }\end{array}$} & \multirow{2}{*}{$\begin{array}{l}\text { Change in } \\
\text { amplitude } \\
\text { (end/onset) }\end{array}$} & \multirow{2}{*}{$\begin{array}{l}\text { Right atrial } \\
\text { perfusion }\end{array}$} & \multirow{2}{*}{$\begin{array}{l}\text { Coronary } \\
\text { pressure }\end{array}$} & \multirow{2}{*}{$\begin{array}{l}\text { Cardiac } \\
\text { rate }\end{array}$} & \multirow{2}{*}{$\begin{array}{c}\text { Incorporation } \\
\text { of } \\
{\left[{ }^{4} \mathrm{C}\right] \text { lysine }}\end{array}$} \\
\hline & Systolic & Diastolic & & & & & & \\
\hline & \multicolumn{2}{|c|}{$m m \mathrm{Hg}$} & $m m \mathrm{Hg}$ & & $\begin{array}{c}m l / \min / g \\
d r y w t\end{array}$ & $m m \mathrm{Hg}$ & beats $/ \min$ & $\begin{array}{c}\text { Amol lysine/g } \\
\text { protein N }\end{array}$ \\
\hline I $(10)$ & $3.1 \pm 0.7$ & $-0.3 \pm 0.2$ & 3.4 & $1.06 \pm 0.1$ & $14.5 \pm 0.2$ & $33 \pm 4$ & $169 \pm 10$ & $35.2 \pm 2.6$ \\
\hline II (10) & $11.2 \pm 0.8$ & $3.5 \pm 1.8$ & 7.7 & $1.10 \pm 0.10$ & $14.0 \pm 0.2$ & $39 \pm 4$ & $188 \pm 9$ & $56.4 \pm 4.2$ \\
\hline$P(I$ vs. II $)$ & $<0.001$ & $<0.05$ & & NS & NS & NS & NS & $<0.001$ \\
\hline III (7) & $22.2 \pm 1.6$ & $11.2 \pm 2.4$ & 11.0 & $1.01 \pm 0.05$ & $14.5 \pm 0.2$ & $41 \pm 4$ & $174 \pm 8$ & $36.6 \pm 2.2$ \\
\hline$P($ III vs. I $)$ & $<0.001$ & $<0.001$ & & NS & NS & NS & NS & NS \\
\hline$P($ III vs. II $)$ & $<0.001$ & $<0.01$ & & NS & NS & NS & NS & $<0.001$ \\
\hline IV (6) & $2.1 \pm 0.07$ & $-1.0 \pm 0.1$ & 3.1 & $1.10 \pm 0.05$ & $8.6 \pm 0.05$ & $32 \pm 4$ & $162 \pm 9$ & $39.0 \pm 2.0$ \\
\hline$V(6)$ & $2.8 \pm 0.04$ & $-0.9 \pm 0.08$ & 3.7 & $0.97 \pm 0.05$ & $19.3 \pm 0.05$ & $32 \pm 4$ & $180 \pm 10$ & $38.2 \pm 1.7$ \\
\hline$P($ IV vs. V $)$ & NS & NS & & NS & $<0.001$ & NS & NS & NS \\
\hline VI (6) & $2.7 \pm 0.04$ & $-0.9 \pm 0.07$ & 3.6 & $0.96 \pm 0.05$ & $33.9 \pm 0.06$ & $36 \pm 3$ & $171 \pm 9$ & $43.3 \pm 3.0$ \\
\hline$P($ VI vs. IV) & NS & NS & & NS & $<0.001$ & NS & NS & NS \\
\hline$P(\mathrm{VI}$ vs. $\mathrm{V})$ & NS & NS & & NS & $<0.001$ & NS & NS & NS \\
\hline VII (2) & 6.5 & 0.3 & 6.2 & 1.0 & 43.0 & 34 & 176 & 47.9 \\
\hline
\end{tabular}

Groups I, II, and III = variations of right ventricular pressure with constant right atrial perfusion load. Groups IV, V, and $\mathrm{VI}=$ changes in right atrial perfusion with minimal changes in right ventricular pressures. Numbers in parentheses under "Group" indicate number of separate studies. Values are expressed as means of $3 \mathrm{~h}$ of perfusion \pm SE. In group VII the means only are listed. $P$ values represent determination of significance (Student's $t$ ) between groups indicated. Incorporation of $\left[{ }^{14} \mathrm{C}\right]$ lysine: See Methods.

tion of right ventricular systolic and diastolic pressures, there was an increase in "amplitude" or $\Delta \mathrm{P}$ (Table I, groups I and II). The negative value for the diastolic pressure in group I indicates a fall below the preset baseline but is not significantly different from the base-line reading of zero. With the rise in right ventricular pressure, there was no evidence of progressive decrease in myocardial competence with this load since the "amplitude" at the end of the perfusion period of $3 \mathrm{~h}$ was the same as that at the onset (ratio of amplitudes, end/onset $=1.10$ compared to 1.06 in the low pressure group (Table I, groups I and II). Incorporation of $\left[{ }^{14} \mathrm{C}\right]$ lysine into right ventricular protein was significantly increased by $60 \%$ in the moderately elevated pressure group (group II) as compared to that of the normal pressure group (group I).

With further increase in resistance to right ventricular ejection (group III, Table I) and increase in systolic pressure in the right ventricles to $22 \mathrm{~mm} \mathrm{Hg}$, there was a concomitant rise in the right intraventricular diastolic pressure and the amplitude of contraction. There was no decrease in the amplitude during the $3 \mathrm{~h}$ of perfusion (amplitude ratio, end/onset $=1.01$; see $\mathrm{Ta}$ ble I, group III). Despite this increased contractile effort, there was now a fall in lysine incorporation by mixed right ventricular protein (incorporated lysine $=$
$36.6 \mu \mathrm{mol} \mathrm{lysine} / \mathrm{g}$ protein $\mathrm{N}$ compared to 56.4 in the moderately elevated pressure group II).

The data obtained in this model so far indicated that right ventricular protein synthesis increased with a 2-3fold increase in pressure but then dropped to the "control" levels (groups III and I, Table I) as the pressure increased further. The initial rise in right ventricular protein synthesis with afterloading of moderate degree is similar to that seen with the left ventricle perfused with the same coronary flow (6), but the falloff in protein synthesis with further elevations of ventricular pressure was not previously seen in the left ventricular perfusion systems.

Several possibilities for the fall in right ventricular protein synthesis in the face of increasing ventricular pressure remained to be explored. These included (a) alterations in coronary pressure with increases in right ventricular afterload, (b) decreased intracellular free lysine pool specific activity as the right ventricular pressure reached its maximal levels, (c) progressive right ventricular anoxia in the high pressure group either due to shunting or decreased total coronary flow, and $(d)$ marked impairment of contractility.

\section{Coronary Pressure and Total Flow}

The decrease in synthesis in group III (Table I) was not due to alterations in total coronary perfusion flow or 
TABLE II

Specific Activity of the Intracellular Free Lysine Pool and Right Ventricular Systolic Pressures

\begin{tabular}{|c|c|c|}
\hline $\begin{array}{l}\text { Number of } \\
\text { study }\end{array}$ & $\begin{array}{c}\text { Right } \\
\text { ventricular } \\
\text { systolic } \\
\text { pressure* }\end{array}$ & $\begin{array}{l}{\left[{ }^{14} \mathrm{C}\right] \text { Lysine }} \\
\text { specific activity } \\
\text { Intracellular } \\
\text { pool/perfusatef }\end{array}$ \\
\hline \multicolumn{3}{|c|}{$m m \mathrm{Hg}$} \\
\hline 1 & 5 & 0.70 \\
\hline 2 & 8 & 0.68 \\
\hline 3 & 13 & 0.62 \\
\hline 4 & 18 & 0.69 \\
\hline 5 & 20 & 0.64 \\
\hline 6 & 25 & 0.71 \\
\hline
\end{tabular}

* Systolic pressures were means for $3 \mathrm{~h}$ of perfusion in each study.

$\ddagger$ The specific activity of the $\left[{ }^{14} \mathrm{C}\right]$ lysine in the intracellular free lysine pool is expressed as a fraction of the perfusate lysine specific activity in order to correct for different activities used on different days. The specific activities of the pools were determined at the end of the 3 -h perfusion period. The specific activity in the perfusate varied from $38,300-48,000$ $\mathrm{cpm} / \mu \mathrm{mol}$ lysine.

pressure since both remained stable with the rise in right ventricular pressures from $3-4 \mathrm{~mm} \mathrm{Hg}$ to more than $20 \mathrm{~mm} \mathrm{Hg}$ (Table I, groups I, II, and III).

\section{Intracellular Free Lysine Pool}

The diminished protein incorporation of lysine in the highest pressure group was not caused by altered specific activity of the intracellular free lysine pool since the latter remained essentially unchanged after $3 \mathrm{~h}$ of perfusion at different pressures (Table II).

In two studies with pooled right ventricles perfused for only $25-30 \mathrm{~min}$, the specific activity of the intracellular free lysine pool in ventricles perfused at high pressures $(20 \mathrm{~mm} \mathrm{Hg})$ was not lower than that in ventricles perfused with low pressures $(4 \mathrm{~mm} \mathrm{Hg}$ ). Thus, with a perfusate $\left[{ }^{14} \mathrm{C}\right]$ lysine, specific activity of 48,000 $\mathrm{cpm} / \mu \mathrm{mol}$, the specific activity of the low pressure group was $29,000 \mathrm{cpm} / \mu \mathrm{mol}$, and in the high pressure group 33,000 . Therefore, the drop in synthesis in the high pressure group was not due to early delayed equilibration of the intracellular free lysine pool.

\section{Progressive Right Ventricular Hypoxia}

Relative right ventricular anoxia could be suggested as a cause of the fall in right ventricular protein synthesis with the highest pressure group for two reasons: first, a shift in coronary perfusion from the right to left heart as the right ventricular pressure increased; and second, restricted total coronary perfusion with inade- quate total coronary supply of oxygen to meet contractile and protein synthetic requirements.

Measurement of the activity of the albumin or macroaggregated $\left[{ }^{131} \mathrm{I}\right]$ albumin after one circulation of the label through the heart showed no significant change from controls when the pressure was increased to the maximum levels used in this study (Table III). It was therefore unlikely that any significant shift or reduction in coronary flow occurred during the $3 \mathrm{~h}$ of perfusion with high pressures, and selective progressive anoxia in the right ventricles subjected to maximal afterloads was also unlikely.

TABLE III

Ventricular Uptake of Albumin or Macroaggregated [131I]Aibumin 1-3 s after Introduction of the Labels into the Aortic Cannula

\begin{tabular}{|c|c|c|c|}
\hline $\begin{array}{l}\text { Right ventricular } \\
\text { systolic pressure }\end{array}$ & $\mathrm{RV}^{*}$ & LV* & $\mathrm{RV} / \mathrm{LV}$ \\
\hline$m m \mathrm{Hg}$ & \multicolumn{2}{|c|}{$c p m / g$ wet ventricular wt } & \\
\hline \multirow[t]{17}{*}{$4-5$} & 25,500 & 24,300 & 1.04 \\
\hline & 3,413 & 3,592 & 0.95 \\
\hline & 4,780 & 3,610 & 1.32 \\
\hline & 3,490 & 3,200 & 1.09 \\
\hline & 9,410 & 10,100 & 0.93 \\
\hline & 2,330 & 2,170 & 1.07 \\
\hline & 28,900 & 21,500 & 1.34 \\
\hline & 4,520 & 4,400 & 1.02 \\
\hline & 2,010 & 2,610 & 0.77 \\
\hline & 4,730 & 2,430 & 1.94 \\
\hline & 4,450 & 6,000 & 0.74 \\
\hline & 5,600 & 4,800 & 1.16 \\
\hline & 6,800 & 6,800 & 1.00 \\
\hline & 10,700 & 9,480 & 1.12 \\
\hline & 5,850 & 4,370 & 1.30 \\
\hline & 8,170 & 6,390 & 1.27 \\
\hline & 20,900 & 14,600 & 1.40 \\
\hline Mean & & & $1.14 \pm 0.07$ \\
\hline \multirow[t]{14}{*}{$18-25$} & 11,800 & 12,000 & 0.98 \\
\hline & 6,829 & 4,030 & 1.69 \\
\hline & 8,750 & 10,400 & 0.84 \\
\hline & 17,900 & 17,200 & 1.04 \\
\hline & 9,900 & 11,000 & 0.90 \\
\hline & 9,810 & 7,550 & 1.30 \\
\hline & 4,050 & 3,530 & 1.15 \\
\hline & 11,500 & 8,810 & 1.31 \\
\hline & 2,660 & 1,500 & 1.77 \\
\hline & 16,200 & 22,800 & 0.71 \\
\hline & 17,200 & 17,400 & 0.99 \\
\hline & 1,770 & 2,210 & 0.80 \\
\hline & 19,200 & 12,100 & 1.59 \\
\hline & 23,000 & 27,000 & 0.85 \\
\hline Mean & & & $1.14 \pm 0.09$ \\
\hline
\end{tabular}

* RV and LV are right and left ventricles, respectively. The counts are varied on different days due to the varied activity used on those days. 
TABLE IV

Lactate Production by Hearts and Lactate and ATP Content of Right Ventricles after $3 \mathrm{~h}$ of Perfusion with Afterload Stress Compared to Right Ventricular Protein Synthesis

\begin{tabular}{cccccc}
\hline Coronary flow & $\begin{array}{c}\text { RV peak } \\
\text { systolic } \\
\text { pressure }\end{array}$ & $\begin{array}{c}\text { RV protein } \\
\text { synthesis }\end{array}$ & $\begin{array}{c}\text { RV ATP } \\
\text { content }\end{array}$ & $\begin{array}{c}\text { RV lactate } \\
\text { content }\end{array}$ & Lactate production \\
\hline ml/min & $m m ~ H g$ & $\mu m o l$ lysine & $\mu m o l / g ~$ & $\begin{array}{c}\mu m o l / g \\
\text { wet wt }\end{array}$ & $\begin{array}{c}\mu m o l / m i n / g \\
\text { wet wt }\end{array}$ \\
4.0 (I)* & $3-4$ & $35.2 \pm 2.6$ & $109 \pm 5$ & $6.0,3.7$ & $0.75,0.83$ \\
(II) & $10-12$ & $56.4 \pm 4.2$ & $110 \pm 6$ & $4.7,3.4$ & $0.62,0.75$ \\
(III) & $20-26$ & $36.6 \pm 2.2$ & $100 \pm 5$ & $6.3 \pm 0.2$ & $1.16 \pm 0.1$ \\
6.0 (VIII) & $3-4$ & $33.3 \pm 2.3$ & 128 & $3.4,3.8$ & $0.30,0.60$ \\
(IX) & $10-12$ & $50.0 \pm 2.7$ & 128 & $5.8,4.5$ & $0.50,0.48$ \\
(X) & $20-28$ & $35.1 \pm 3.5$ & $129 \pm 5$ & $4.1 \pm 0.3$ & $0.42 \pm 0.04$ \\
\hline
\end{tabular}

* The numbers in parentheses and the figures for protein synthesis represent the groups described in Tables I and V. RV, right ventricle. Lactate produced is from both ventricles.

$A T P$ content. The effect of restricting coronary flow on ATP levels was measured by determination of the ATP contents in the right ventricles at the end of perfusion at the different pressure levels. With perfusion with the coronary flow of $4 \mathrm{ml} / \mathrm{min}$, the ATP content was maintained at $110 \pm 5$ (SE) $\mu \mathrm{mol}$ for $3 \mathrm{~h}$ of perfusion. There was no significant fall in the ATP content in the right ventricles as the right ventricular pressure was increased (Table IV). Furthermore, the ATP contents at the maximum pressure levels, where protein synthesis fell off, were not significantly different from the levels where protein synthesis was increased (Table IV, groups I, II, and III).

Lactate. Although lactate content in the right ventricles of the maximum afterload group was not significantly different from that in the lowest pressure group, measurements of lactate production by the entire heart (collection of coronary effluent) indicated that lactate produced in maximum pressure stress almost doubled that in the lower pressure groups (Table IV, group III).

\section{Right Ventricular Contractile Action}

As one index of contraction, amplitude or $\Delta \mathrm{P}$, defined as the difference between systolic and diastolic right ventricular cavity pressures, was continuously recorded. As afterload was increased from 3-5 $\mathrm{mm} \mathrm{Hg}$ to $22 \mathrm{~mm} \mathrm{Hg}$, and the diastolic pressure rose, the amplitudes progressively increased, (Table I, groups I, II, and III). Since protein synthesis fell at the higher afterload levels, it was also of interest to examine other parameters of contractility. At all levels of right ventricular systolic pressure $\mathrm{dP} / \mathrm{dT} \max$ was closely correlated with $\Delta \mathrm{P}$ (Fig. 4), and both $\mathrm{dP} / \mathrm{dT}$ and $\Delta \mathrm{P}$ increased (Table $\mathrm{I}$, Fig. 5) with elevation of pressure.

Right ventricular protein synthesis with coronary flow increased to $6 \mathrm{ml} / \mathrm{min}$. In spite of the maintenance of ATP at a relatively constant level in the hearts perfused with a coronary flow of $4 \mathrm{ml} / \mathrm{min}$, even at maximum right ventricular pressures, the lactate production increased. Hence, it was entirely possible that the increased oxygen requirement at these pressures (12-14) in the presence of right ventricular hypoxia left little available for protein synthesis. The latter might explain the drop in protein synthesis at the high afterload pressures. Hence, hearts were perfused with higher coronary flows of $6 \mathrm{ml} / \mathrm{min}$ (equivalent to $40 \mathrm{ml} / \mathrm{min} / \mathrm{g}$ dry wt) (Table V). Increases in coronary flow above this

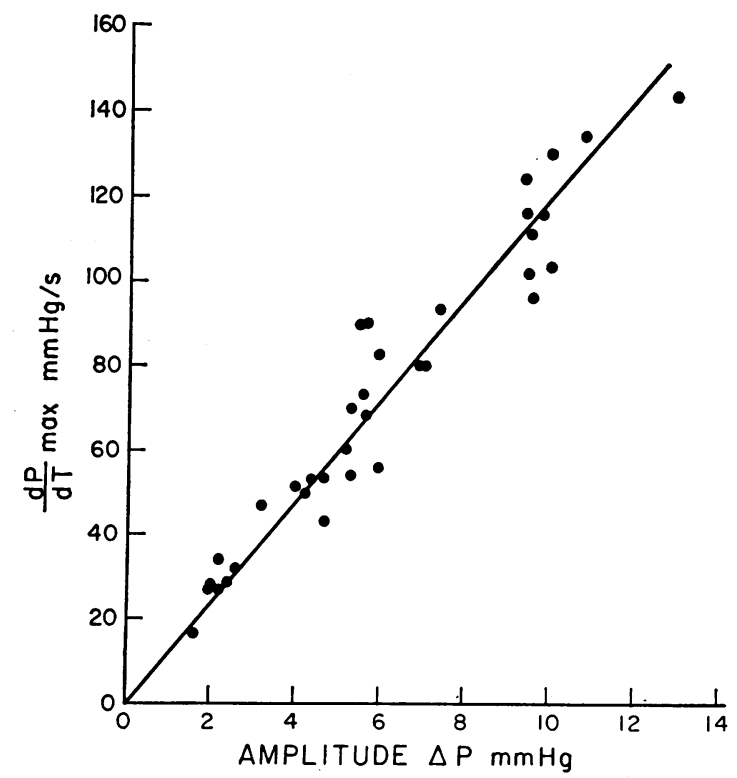

FIGURE 4 Correlation between amplitude of contractions or $\Delta \mathbf{P}$ (difference between right ventricular systolic and diastolic pressures) and $\mathrm{dP} / \mathrm{dT} \max$ as the afterload of the right ventricles was increased from 3 to $25 \mathrm{~mm} \mathrm{Hg}$. The coronary flow was $4 \mathrm{ml} / \mathrm{min}$ or $25 \mathrm{ml} / \mathrm{min} / \mathrm{g} d r y$ wt. 
TABLE V

Protein Synthesis in Right Ventricles with Restricted and Constant Coronary Flow of $6 \mathrm{ml} / \mathrm{min}(40 \mathrm{ml} / \mathrm{min} / \mathrm{g} \mathrm{dry} \mathrm{wt)}$ with Changes in Right Ventricular Pressure or Right Atrial Perfusion Load

\begin{tabular}{|c|c|c|c|c|c|c|c|c|}
\hline \multirow[b]{2}{*}{ Group } & \multicolumn{2}{|c|}{ Right ventricular pressure } & \multirow{2}{*}{$\underset{\text { (mean) }}{\text { Amplitude }}$} & \multirow{2}{*}{$\begin{array}{l}\text { Change in } \\
\text { amplitude } \\
\text { (end/onset) }\end{array}$} & \multirow{2}{*}{$\begin{array}{l}\text { Right atrial } \\
\text { perfusion }\end{array}$} & \multirow{2}{*}{$\begin{array}{l}\text { Coronary } \\
\text { pressure }\end{array}$} & \multirow{2}{*}{$\begin{array}{l}\text { Cardiac } \\
\text { rate }\end{array}$} & \multirow{2}{*}{$\begin{array}{c}\text { Incorporation } \\
\text { of } \\
{\left[{ }^{14} \mathrm{C}\right] \text { lysine }}\end{array}$} \\
\hline & Systolic & Diastolic & & & & & & \\
\hline & \multicolumn{2}{|c|}{$m m \mathrm{Hg}$} & $m m \mathrm{Hg}$ & & $\underset{d r y w t}{\operatorname{ml} / \min / \mathrm{g}}$ & $m m \mathrm{Hg}$ & beats/min & $\begin{array}{c}\text { umol lysine } / \mathrm{g} \\
\text { protein } N\end{array}$ \\
\hline VIII (11) & $3.03 \pm 0.8$ & $-2.1 \pm 0.6$ & 5.1 & $1.01 \pm 0.1$ & $2.6 \pm 0.1$ & $42 \pm 3$ & $171 \pm 4$ & $33.3 \pm 2.3$ \\
\hline $\begin{array}{l}\text { IX }(9) \\
\quad P(\text { VIII vs. IX) }\end{array}$ & $\begin{array}{c}10.9 \pm 0.9 \\
<0.001\end{array}$ & $\begin{array}{l}4.3 \pm 1.5 \\
<0.01\end{array}$ & 6.6 & $\begin{array}{l}1.08 \pm 0.1 \\
\mathrm{NS}\end{array}$ & $\begin{array}{l}2.0 \pm 0.2 \\
\mathrm{NS}\end{array}$ & $\begin{array}{c}43 \pm 3 \\
\mathrm{NS}\end{array}$ & $\begin{array}{c}164 \pm 5 \\
\text { NS }\end{array}$ & $\begin{array}{c}50.0 \pm 2.7 \\
<0.001\end{array}$ \\
\hline $\mathrm{X}(6)$ & $28.1 \pm 2.0$ & $18.5 \pm 2.4$ & 9.6 & $1.00 \pm 0.5$ & $2.5 \pm 0.2$ & $56 \pm 4$ & $164 \pm 5$ & $35.1 \pm 3.5$ \\
\hline$P(\mathrm{X}$ vs. IX) & $<0.001$ & $<0.001$ & & NS & NS & $<0.05$ & NS & $<0.01$ \\
\hline$P(\mathrm{X}$ vs. VIII $)$ & $<0.001$ & $<0.001$ & & NS & NS & $<0.05$ & NS & NS \\
\hline VIII(11) & $3.0 \pm 0.8$ & $-2.1 \pm 0.6$ & 5.1 & $1.01 \pm 0.1$ & $2.6 \pm 0.1$ & $42 \pm 3$ & $171 \pm 4$ & $33.3 \pm 2.3$ \\
\hline $\mathrm{XI}(5)$ & $2.2 \pm 0.8$ & $-2.1 \pm 0.8$ & 4.3 & $1.20 \pm 0.1$ & $22.9 \pm 0.3$ & $40 \pm 4$ & $180 \pm 10$ & $38.8 \pm 3.3$ \\
\hline$P(\mathrm{XI}$ vs. VIII $)$ & NS & NS & & NS & $<0.001$ & NS & NS & NS \\
\hline XII (7) & $3.3 \pm 1.1$ & $0.2 \pm 1.5$ & 4.8 & $1.40 \pm 0.2$ & $41.5 \pm 0.3$ & $41 \pm 3$ & $163 \pm 5$ & $35.6 \pm 2.5$ \\
\hline$P(\mathrm{XII}$ vs. XI $)$ & NS & NS & & NS & $<0.001$ & NS & NS & NS \\
\hline$P(\mathrm{XII}$ vs. VIII $)$ & NS & NS & & NS & $<0.001$ & NS & NS & NS \\
\hline
\end{tabular}

Group VIII represents control for variations in right ventricular pressure (VIII, IX, and X) and also for changes in right atrial perfusion VIII, XI, and XII). Numbers in parentheses under "Group" represent numbers of separate studies. Values are expressed as the means of $3 \mathrm{~h}$ of perfusion $\pm \mathrm{SE} . P$ represents significance (Student's $t$ ) between the groups indicated. Incorporation of lysine: See Methods.

level were avoided since they regularly increased coronary pressures and hence would not be comparable to conditions seen with the group at lower coronary flows

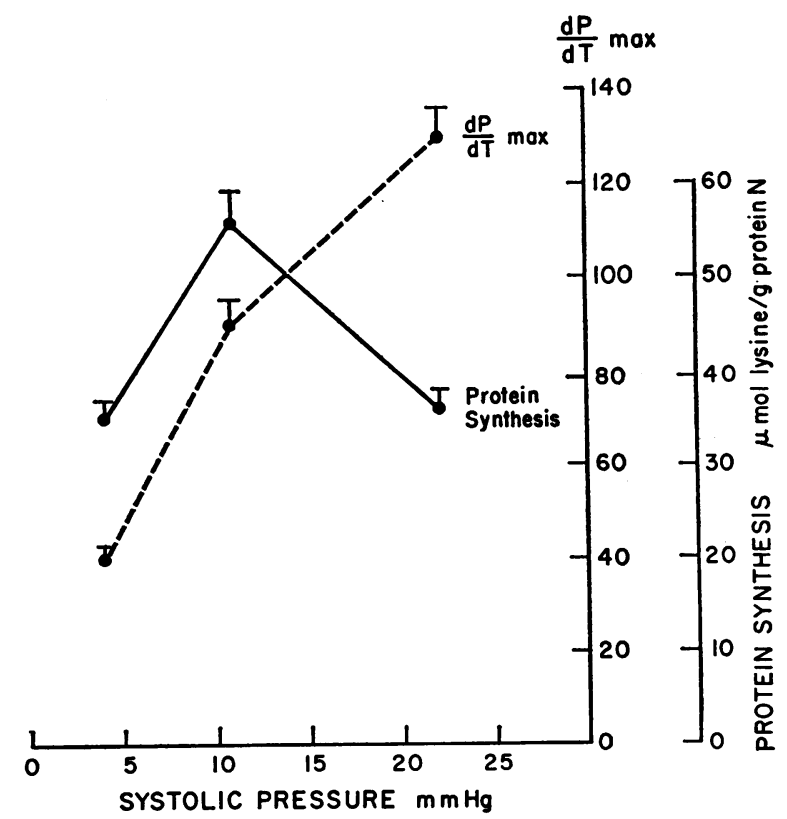

FIGURE 5 Comparison of protein synthesis in right ventricles with $\mathrm{dP} / \mathrm{dT} \max$ at low, moderately elevated and maximum afterloads (groups I, II, and III in Table I). Coronary flow was $4 \mathrm{ml} / \mathrm{min}$. The points are means with SEM.
(Table I). Since the coronary perfusion was increased, the right atrial perfusion was adjusted to a lower level in the pressure overload groups (Table V, groups VIII, IX, and $X$ ) so that the combined right atrial load (atrial perfusion and coronary flow emptying into the right atrium) were essentially the same as in hearts with lower coronary flows (Table I, groups I, II, and III).

The protein synthetic response in this group was almost identical to that seen with lower flows. Increased protein synthesis accompanied elevations in right ventricular pressure followed by a drop to control levels as the pressure increased maximally. The drop occurred despite significantly higher ATP and lower lactate content and production compared to the lower coronary flow group (Table IV), group X compared to group III).

Increase of right atrial perfusion load in the face of restricted and constant coronary artery perfusion and minimum elevation in right ventricular pressures

Coronary flow $4 \mathrm{ml} / \mathrm{min}$ (Table I, groups $I V, V$, and $V I)$. With the pulmonary catheter wide open it was possible to more than double the right atrial perfusion from 9 to $19 \mathrm{ml} / \mathrm{min} / \mathrm{g}$ dry wt without effecting alterations in right ventricular pressures, amplitude of contractions, or ratio of amplitudes (Table I, groups IV and V). Furthermore, there was no significant alteration in protein incorporation of lysine in either right or left ventricles between the two groups after $3 \mathrm{~h}$ of per- 
fusion. With the atrial perfusion load elevated to $34 \mathrm{ml} /$ $\mathrm{min} / \mathrm{g}$ dry wt there was a slight increase in incorporation of $\left[{ }^{11} \mathrm{C}\right]$ lysine into right ventricle protein (Table I, group VI) but this was not statistically different from group IV. Further increases in atrial perfusion to $43 \mathrm{ml} /$ $\mathrm{min} / \mathrm{g}$ dry wt in two studies (group VII) did result in an increase in lysine incorporation by protein, but it was of interest that there was a concomitant increase in right ventricular pressure.

Coronary flow $6 \mathrm{ml} / \mathrm{min}$. Right ventricular protein synthesis again remained unaltered with volume loading (Table V, groups VIII, XI, and XII).

\section{DISCUSSION}

The present report describes a cardiac perfusion model which permits comparison of right ventricular protein synthesis with pressure and volume stresses under carefully controlled and constant coronary artery perfusion.

In estimating protein synthesis from measurements of incorporation of a labeled amino acid, such as lysine, into mixed cardiac protein, a major problem involves the determination of the precursor pool specific activity of the amino acid used as the tracer since the specific activity in the precursor pool may be different from that in the extracellular or even in the mixed intracellular pool $(10,15-17)$. In skeletal muscle or in the guinea pig heart in vitro, with or without pressure stress, equilibration with constant specific activity $\left[{ }^{11} \mathrm{C}\right]$ lysine shows that the specific activity of the intracellular pool reaches only $70 \%$ of that in the perfusate after hours $(10,18$, 19). The equilibration in the right ventricle presented here was identical. However, the immediate precursor pool specific activity, i.e., lysyl-tRNA, was not the same as that of the mixed pool, but in the guinea pig heart appeared to bear a constant relationship to the mixed pool (10). Thus, the specific activity of the phenol-extracted RNA-bound lysine was $60 \%$ of that in the mixed intracellular pool regardless of the pressure load (10). In view of the difficulty in obtaining the $t R N A$ specific activity in each heart, the intracellular lysine pool specific activity was used to calculate protein synthesis, and although the absolute values presented here may be lower than the true values by $40 \%$, the data have the same qualitative direction.

With this perfusion model, excessive volume load to the right heart was not associated with any consistent increase in protein synthesis in contrast to that seen with elevated right ventricular pressures. Increase in volume load increases stroke volume and cardiac volume and causes an increase in wall tension and stretch in spite of unchanging pressure. However, this tension and shortening against the low pressure head is apparently not a sufficient stimulus for increased cardiac protein synthesis in the acute model.
Although the lack of stimulation of protein synthesis by acute volume loading in the young guinea pig right ventricle with controlled coronary flow is similar to the findings in left ventricles of perfused rat hearts (20), they are not in agreement with our earlier observations in guinea pig left heart perfusions or with data obtained from in vivo studies of aortic insufficiency where protein synthesis in the left ventricle was increased. The difference may be due to the difference in the model but may also be due to the finding that coronary flow was markedly increased in left ventricular loading (6).

In contrast to the lack of effect of acute right ventricular volume loading on protein synthesis, increased pulmonary artery outflow resistance (afterload) resulted in significant increase in protein synthesis despite the identical coronary flow as in the low pressure or volume loaded groups. Augmented protein synthesis has been regularly seen in the left ventricle accompanying elevated aortic pressure both in vitro $(6,7,8,20)$ and in vivo $(21,22,23)$, but it has been difficult to separate the protein synthesis-pressure relationship from changes in coronary perfusion (20), since afterload in the left ventricular models increases coronary flow during the application of the afterload. Increased protein synthesis has also been seen in the nonperfused papillary muscle stimulated with increased tension (24), although here passive stretch also showed some increase in synthesis. The present study supports a protein synthesis-pressure relationship which is independent of coronary perfusion.

The increase in right ventricular protein synthesis with moderate elevation in pressure or afterload was reversed when the afterload was increased to maximal levels (group III, Table I). The increase in afterload did not result in any significant alteration in coronary perfusion pressure, intracellular free lysine pool specific activity, decreased contractility, or significant shunting of coronary circulation from right to left ventricles. Thus, the fall in protein synthesis could not be ascribed to such changes.

It should also be recognized that in this model there was no functioning pulmonic valve. This might be responsible for some of the rise in end-diastolic pressure in group III rather than progressive cardiac failure.

Furthermore, ATP levels were the same at high and low pressures in the right ventricle. Since the ATP level rapidly reflects the degree of anoxia (25-27), shunting from the right to left ventricle during the $3 \mathrm{~h}$ of high pressure perfusion with selective right ventricular anoxia would be expected to reduce the ATP within $20 \mathrm{~min}$ to levels far below those seen here after $3 \mathrm{~h}$ (28).

However, it is recognized that this model perfused with Krebs-Henseleit solution was relatively hypoxic when compared to the in vivo situation. This level of 
hypoxia has apparently not interfered with the ability of the left ventricle to respond to stress with marked increments of protein synthesis in vitro $(6,7)$, nor prevented the similar response of the right ventricle when pressures were increased 3-4-fold in the present study. Yet, as afterload reached the maximum used in this preparation, protein synthesis fell. With this degree of pressure elevation, oxygen requirement to maintain or increase contractility would be greatly increased $(4,29$, 30 ), and the coronary flow of $4 \mathrm{ml} / \mathrm{min}$ may not be adequate to supply sufficient oxygen to satisfy energy requirements for maintenance of both contractility and augmented protein synthesis. This is suggested by the increased lactate production in this group.

When the coronary flow was increased to $6 \mathrm{ml} / \mathrm{min}$, the protein synthetic response of the right ventricle was identical to that seen with the more restricted coronary flow of $4 \mathrm{ml} / \mathrm{min}$, i.e., a significant increase in synthesis as the pressure increased 3-4-fold again followed by a fall in synthesis as the pressure reached its maximum levels. But in this group protein synthesis decreased despite a significant fall in lactate production and right ventricular lactate content, as well as a rise in ATP and ATP/lactate ratios (Table IV, group $X$ ). The data would suggest that the fall in protein synthesis at the maximum pressures, at least in this group, was not solely due to progressive hypoxia during perfusion.

Recently it has been demonstrated that alterations in hydrostatic pressure may affect protein synthesis, and a similar anomalous protein synthesis-pressure relationship has been described in subcellular systems (31). Progressive increases in hydrostatic pressures first increased and then decreased protein synthesis. Although the pressures used were far above those used in this study, it is of interest that the right ventricles in the afterload studies responded similarly.

In summary, the present report presents a perfusion model which suggests a direct pressure-protein synthesis relationship in the right ventricle isolated from the effects of altered coronary flow. The data have demonstrated that a moderate pressure load in the right ventricle elicits an early increase in protein synthesis while volume loading does not, and suggest a ventricular pressure receptor affecting protein synthesis. The latter may indeed be akin to the osmotic pressure receptor postulated in the liver $(32,33)$ or similar to the ribosome receptor suggested earlier (31). With further increases in pressure, there is an anomalous decrease in right ventricular protein synthesis. Although this may be due to an increase in hypoxia with lower coronary flows, the data obtained with higher flows indicate that hypoxia maý not be the sole cause.

\section{ACKNOWLEDGMENTS}

The authors wish to acknowledge with thanks the secretarial assistance of Mrs. Jean E. Miller and the illustrations by Miss Josephine Neglia.

This work was supported in part by grants from the U. S. Public Health Service (HL 09562), the Veterans Administration, and the Bear Foundation.

\section{REFERENCES}

1. Meerson, F. Z. 1962. Compensatory hyperfunction of the heart and cardiac insufficiency. Circ. Res. 10: 250258.

2. Grimm, A., F. Kuboto, and W. V. Whitehorn. 1966. Ventricular nucleic acids and protein levels with myocardial growth and hypertrophy. Circ. Res. 19: 552-558.

3. Hatt, P., J. Berjal, and B. Swynghedauw. 1970. Le myocarde ventriculaire dans l'insuffisance cardiaque experimentale par l'insuffisance aortique chez le lapin. Arch. Mal. Couer Vaiss. 3: 383-407.

4. Hull, E, 1967. Cardiac output: hypertrophy and dilatation of the heart. In Pathologic Physiology. W. A. Sodeman and W. A. Sodeman, Jr., editors. W. B. Saunders Co., Philadelphia. 4th edition. 380-447.

5. Kossman, E. 1965. Diseases of the heart and blood vessels. Nomenclature and criteria for diagnosis. Committee of New York Heart Association, Little, Brown and Co., Boston. 6th edition. 52 .

6. Schreiber, S. S., M. Oratz, and M. A. Rothschild. 1966. Protein synthesis in the overloaded heart. Am. J. Physiol. 211 : 314-318.

7. Schreiber, S. S., M. Oratz, C. Evans, I Gueyikian, and M. A. Rothschild. 1970. Myosin, myoglobin and collagen synthesis in acute cardiac overload. Am. J. Physiol. 219: 481-486.

8. Kako, K., and R. Minelli. 1969. Regulation of leucine incorporation into cardiac protein by work loads. $E_{x-}$ perientia (Basal). 25: 34-36.

9. Schreiber, S. S. 1973. Effects of overload on cardiac muscle protein synthesis leading ultimately to hypertrophy. How to approximate the "true" rates of protein synthesis in the face of lack of intracellular homogeneity. Mt. Sinai J. Med. 40: 482-490.

10. Schreiber, S. S., M. Oratz, C. Evans, F. Reff, I Klein, and M. Rothschild. 1973. Cardiac protein degradation in acute overload in vitro: reutilization of amino acids. Am. J. Physiol. 224: 338-345.

11. McDonald, T. F., and D. P. McLoed. 1973. Anoxic atrial and ventricular muscle electrical activity, cell potassium, and metabolism. A comparative study. $J$. Mol. Cell. Cardiol 5: 149-159

12. Braunwald, E., S. J. Sarnoff, R. S. Case, W. N. Stainsby, and G. H. Welch, Jr. 1958. Hemodynamic determinants of coronary flow. Effect of changes in aortic pressure and cardiac output on the relationship between myocardial oxygen consumption and coronary flow. Am. J. Physiol. 192: 157-163.

13. Sonnenblick, E. H., D. Spiro, and H. M. Spotnitz. 1964. The ultrastructural basis of Starling's law of the heart. The role of the sarcomere in determining ventricular size and stroke volume. Am. Heart J. 68: 336-346.

14. Brachfeld, N., and J. S. LaDue. 1967. Congestive heart failure, coronary insufficiency and myocardial infarction. In Pathologic Physiology. W. A. Sodeman and W. A. Sodeman, Jr., editors. W. B. Saunders Co., Philadelphia. 4th edition. 448-502. 
15. Righetti, P., E. P. Little, and G. Wolf. 1971. Reutilization of amino acids in protein synthesis in HeLa cells. J. Biol. Chem. 246: 5724-5732.

16. Rannels, D. E., and H. E. Morgan. 1973. Compartmentalization of the intracellular phenylalanine pool in the perfused rat heart. Fed. Proc. 32: 532:. (Abstr.)

17. Martin, A. F., G. Prior, and R. Zak. 1973. Early kinetics of labeling of aminoacyl tRNA and intracellular free amino acid pool in rat heart. Fed. Proc. 32: 532. (Abstr.)

18. Schreiber, S. S., K. Briden, M. Oratz, and M. A. Rothschild. 1972. Ethanol, acetaldehyde and myocardial protein synthesis. J. Clin. Invest. 51 : 2820-2826.

19. Gan, J. C., and H. Jeffay. 1967. Origins and metabolism of the intracellular amino acid pools in rat liver and muscle. Biochim. Biophys. Acta. 148 : 448-459.

20. Hjalmarson, $\AA$., and O. Isaksson. 1972. In vitro work load and rat heart metabolism. I. Effect on protein synthesis. Acta Physiol. Scand. 86:126-144.

21. Tomita, K. 1966. Studies on myocardial protein metabolism in cardiac hypertrophy. Jap. Heart J. 7: 566-589.

22. Fanburg, B. L., B. I. Posner, and S. Matsushita. 1971. Ribonucleis acid synthesis in experimental cardiac hypertrophy. In Cardiac Hypertrophy. Norman Alpert, editor. Academic Press, Inc., New York. 273-282.

23. Rabinowitz, M., and R. Zak. 1972. Biochemical and cellular changes in cardiac hypertrophy. Annu. Rev. Med. 23: 245-262.

24. Peterson, M., and M. Lesch. 1972. Protein synthesis and amino acid transport in the isolated rabbit right ventricular papillary muscle. Circ. Res. 31: 317-327.
25. Jefferson, L. S., E. B. Wolpert, K. E. Giger, and H. E. Morgan. 1971. Regulation of protein synthesis in heart muscle. III. Effect of anoxia on protein synthesis. J. Biol. Chem. 246: 2171-2178.

26. Scheuer, J. 1972. The effect of hypoxia on glycolytic ATP production. J. Mol. Cell. Cardiol. 4: 689-692.

27. Hearse, D., Jr., and E. B. Chain. 1972. The role of glucose in the survival and 'recovery' of the anoxic and isolated perfused rat heart. Biochem. J. 128: 1125-1133.

28. Neely, J. R., M. J. Rovetto, J. T. Whitmer, and H. E. Morgan. 1973. Effects of ischemia on function and metabolism of the isolated working rat heart. $\mathrm{Am}$. J. Physiol. 225 : 651-658.

29. Katz, A. M. 1971. Mechanical and biochemical correlates of cardiac contraction. Modern concepts of Cardiovascular Diseases. 40: 39-48.

30. Opie, L. H., K. R. L. Mansford, and P. Owen. 1971. Effects of increased heart work on glycolysis and adenine nucleotides in the perfused heart of normal and diabetic rats. Biochem. J. 124: 475-490.

31. Hildebrand, C. E., and E. C. Pollard. 1973. Hydrostatic pressure effects on protein synthesis. Biophy. $J$. 12: $1235-1250$.

32. Rothschild, M. A., M. Oratz, C. D. Evans, and S. S. Schreiber. 1966. Role of hepatic interstitial albumin in regulating albumin synthesis. Am. J. Physiol. 210: 5766.

33. Oratz, M. 1970. Oncotic pressure and albumin synthesis. In Protein Metabolism. M. A. Rothschild and T. Waldmann, editors. Academic Press, Inc., London. 223238. 